\title{
PRZEGLACD WYBRANYCH PROPOZYCJI ZMIAN LEGISLACYJNYCH W PRZEPISACH DOTYCZACCYCH WYDOBYWANIA GAZU ŁUPKOWEGO
}

\section{Wprowadzenie}

Kwestia złóż gazu łupkowego w Polsce oraz związanych z tym projektowanych przepisów prawa budzi wiele kontrowersji. $Z$ jednej strony istnieje konieczność względnie szybkiego jej uregulowania, z drugiej waga problemu i jego złożoność wymaga dokładnego opracowania rozwiązań. Zamiarem ustawodawcy jest pogodzenie interesów finansowych Państwa z zapewnieniem zrównoważonego rozwoju, ochrony środowiska, bezpieczeństwa publicznego, bezpieczeństwa energetycznego. Ustalenia ustawowe jednocześnie nie mogą stanowić bariery dla podmiotów zainteresowanych eksploatacją złóż, którym zależy przede wszystkim na jasnych i elastycznych zasadach współpracy. Według stanu na 13 czerwca 2013 roku projekt zmiany ustawy - Prawo geologiczne i górnicze i niektórych innych ustaw 12 czerwca został skierowany do Stałego Komitetu Rady Ministrów i Komitetu do Spraw Europejskich.

Jednym z celów projektu jest wprowadzenie regulacji zgodnych z ochroną środowiska i zasadą zrównoważonego rozwoju. ${ }^{1}$ Pełni przede wszystkim rolę dyrektywy wykładni. Gdy pojawiają się wątpliwości co do rodzaju i zakresu obowiązków oraz sposobu realizacji, należy posiłkować się zasadą zrównoważonego rozwoju. ${ }^{2}$

1 Przez zrównoważony rozwój rozumie się taki rozwój społeczno-gospodarczy, w którym następuje proces integrowania działań politycznych, gospodarczych i społecznych, z zachowaniem równowagi przyrodniczej oraz trwałości podstawowych procesów przyrodniczych, w celu zagwarantowania możliwości zaspokajania podstawowych potrzeb poszczególnych społeczności lub obywateli zarówno współczesnego pokolenia, jak i przyszłych pokoleń, zgodnie z art. 3 pkt. 50 ustawy z dnia 27 kwietnia 2001 r. - Prawo ochrony środowiska (tekst jedn. Dz.U. z 2008 r. $\mathrm{Nr} 25$, poz. 150 ze zm.), dalej: p.o.ś.

2 M. Jabłoński, Zasada zrównoważonego rozwoju jako administracyjnoprawny aspekt działania administracji publicznej w Polsce, [w:] M. Rudnicki, M. Jabłoński, K. Sobieraj (red.), Nowoczesna administracja publiczna. Zadania i działalność - uwarunkowania prawne, Lublin 2013, s. 119. 
Przez pojęcie środowiska, zdefiniowane w art. 3 pkt. 39 p.o.ś. rozumie się ogół elementów przyrodniczych, w tym także przekształconych w wyniku działalności człowieka, a w szczególności powierzchnię ziemi, kopaliny, wody, powietrze, krajobraz, klimat oraz pozostałe elementy różnorodności biologicznej, a także wzajemne oddziaływania pomiędzy tymi elementami. Wyliczone komponenty środowiska nie stanowią katalogu zamkniętego, a z przyczyn aksjologicznych należy uznać, że jednym $z$ celów ochrony środowiska jest też ochrona zdrowia i życia ludzi. ${ }^{3}$ Dlatego też omawiając przepisy dotyczące ochrony środowiska pod uwagę bierze się również życie i zdrowie ludzi (np. w odniesieniu do prawa do czystej, zdatnej do spożycia wody), natomiast zasada zrównoważonego rozwoju obejmuje także prawo do zdrowego życia obecnego i przyszłych pokoleń.

\section{Wydobywanie gazu łupkowego. Proces i potencjalne zagrożenia}

Gaz łupkowy lub gaz z łupków to gaz ziemny, który występuje w niekonwencjonalnych złożach zwanych łupkami, w bogatych w materię nieorganiczną drobnoziarnistych skałach ilasto-mułowcowych. Jedną z metod wydobycia gazu z takich złóż jest prowadzenie pionowych i poziomych odwiertów oraz procesu szczelinowania hydraulicznego - wtłaczania specjalnej cieczy, zwanej ,płuczką”. Składa się w ok. $95 \%$ z wody, kilku procent piasku oraz $0,5 \%$ związków chemicznych. Odpowiednie źródło wody umożliwia przygotowanie, a następnie wtłoczenie pod ziemię, pod dużym ciśnieniem, płynu szczelinującego. Płuczka dostaje się do skał przez specjalne orurowanie i krąży w obiegu zamkniętym „napierając” na nie, by spowodować powstanie sieci szczelin, którymi gaz będzie mógł być wydobyty. Po zakończeniu procesu szczelinowania następuje składowanie i utylizacja płynu zwrotnego. Niewielka część płuczki pozostaje pod ziemią. ${ }^{4}$ Odróżnić należy również „wydobywanie węglowodorów” oraz „wydobycie gazu łupkowego”. Pierwsze pojęcie ma szerszy zakres i obejmuje wydobywanie gazu ze złóż konwencjonalnych i niekonwencjonalnych (do tego drugiego rodzaju należy gaz ze skał łupkowych). ${ }^{5}$

Organizacje ekologiczne, przywołując przykłady negatywnego wpływu wydobywania węglowodorów na środowisko, najczęściej za przykład podają USA, światowego potentata w tej dziedzinie. Eksperci słusznie zauważają, że nie można bezkrytycznie pomijać różnic między polskimi i amerykańskimi uwarunkowaniami

3 A. Haładyj, Środowisko - pojęcie, [w:] M. Domagała, A. Haładyj, S. Wrzosek (red.), Encyklopedia Prawa Administracyjnego, Warszawa 2010, s. 274.

M. Woźnicka, Państwowy Instytut Geologiczny, Środowiskowe aspekty wydobycia gazu łupkowego, http:// www.lubelskie.pl/img/userfiles/files/PDF/Rolnictwo/gaz_lupkowy___prezentacje/Panstwowy_Instytut_Geologiczny___Panstwowy_Instytut_Badawczy_Malgorzata_Woznicka.pdf (dostęp: 14.06.2013 r.). straszny-gaz-lupkowy.html (dostęp: 02.06.2013 r.). 
przyrodniczymi i geologicznymi, ${ }^{6} \mathrm{z}$ drugiej strony bez odpowiednio przygotowanych raportów nie ma podstaw do lekceważenia rzeczywistych i potencjalnych zagrożeń. Aktualnie z polecenia Kongresu trwa opracowywanie przez EPA, Agencję ds. Ochrony Środowiska, ogólnokrajowego raportu dotyczącego oddziaływania szczelinowania hydraulicznego na środowisko, który ukaże się w 2014 r. ${ }^{7}$ Wnioski z niego płynące z pewnością będą miały doniosłe znaczenie także dla Polski.

Środowisko to ogół elementów przyrodniczych oraz powiązania między nimi. Być może nadużyciem jest zatem tworzenie katalogu tych elementów, które są najbardziej narażone na negatywny wpływ przy poszukiwaniu i rozpoznawaniu oraz - w przyszłości - wydobywaniu gazu z łupków. Daje się jednak zauważyć, że najwięcej miejsca w rozważaniach i raportach poświęca się wodzie, glebie i powietrzu. ${ }^{8}$ Zdaniem J. Ciechanowicz-McLean, najważniejsza jest ochrona cennych zasobów wód podziemnych będących źródłem wody pitnej. W procesie szczelinowania nie powinno się wykorzystywać wody przeznaczonej do spożycia pochodzącej ze studni głębinowych, a wtłaczane pod ziemię związki chemiczne nie mogą być szkodliwe dla ludzi i środowiska. Poszukiwanie, rozpoznawanie i wydobywanie gazu z łupków nie może ograniczać prawa człowieka do wody dostępnej, czystej i zdatnej do spożycia. $^{9}$

Z kolei J. Macuda przedstawił listę zagrożeń środowiska naturalnego związanych z poszukiwaniem i udostępnianiem złóż niekonwencjonalnych. Wysunął m.in. wniosek, że wpływ prac wiertniczych na środowisko jest bardzo zróżnicowany i w dużej mierze zależy od stanu stopnia zurbanizowania obszaru prowadzenia prac wiertniczych, wrażliwości poszczególnych elementów środowiska i zastosowanej organizacji oraz techniki i technologii wiercenia. Dopuszcza też możliwość, że podczas wiercenia otworów poszukiwawczych istnieje możliwość przekraczania w powietrzu poza terenem wiertni dopuszczalnych stężeń niektórych zanieczyszczeń emitowanych z urządzeń wiertniczych (w tym hałasu). ${ }^{10}$

Katalog potencjalnych zagrożeń i elementów środowiska narażonych na negatywny wpływ wydobywania gazu łupkowego jest otwarty i w pewnym stopniu zależy od konkretnego przypadku. Można mówić tu o pewnej stopniowalność uciążliwości - np. większej szkodliwości emisji hałasu przedsięwzięcia znajdującego się

$6 \quad$ Ibidem.

7 Zasoby gazu i ropy ze złóż niekonwencjonalnych (natural gas and oil from unconventional deposits) - zarys stanu prac poszukiwawczo-wydobywczych, perspektywy rozwoju i możliwe implikacje międzynarodowe, http://www. msz.gov.pl/resource/feec2fc6-b64d-4a16-8104-020f23765052:JCR (dostęp: 14.06.2013 r.).

$8 \quad$ Elementy te były kluczowym przedmiotem badań w trakcie sporządzania przez Państwowy Instytut Geologiczny raportu na temat aspektów środowiskowych szczelinowania hydraulicznego. Zob. Aspekty środowiskowe procesu szczelinowania hydraulicznego wykonanego w otworze Łebień LE-2H, tryb dostępu: http://www.pgi.gov. $\mathrm{pl} / \mathrm{pl} /$ instytut-geologiczny-aktualnosci-informacje/4087-environmental-impact-hydraulic-fracturing-lebien.html (dostęp: 02.06.2013 r.).

9 J. Ciechanowicz-McLean, Prawnośrodowiskowe uwarunkowania wydobywania gazu łupkowego w Polsce, [w:] T. Bąkowski, K. Żukowski (red.), Gdańskie Studia Prawnicze - Studia prawnoadministracyjne. Księga Jubileuszowa profesora Eugeniusza Bojanowskiego, Tom XVIII, Gdańsk 2012, s. 83-85.

10 J. Macuda, Środowiskowe aspekty produkcji gazu ziemnego z niekonwencjonalnych złóż, „Przegląd Geologiczny" 2010, vol. 58, nr 3, s. 270. 
w pobliżu terenów zamieszkałych. Można natomiast stworzyć katalog elementów, które każdorazowo wymagają szczególnej ochrony i postępowania zgodnie z zasadą prewencji. Takim elementem będzie niezbędna w procesie poszukiwania i wydobycia woda.

\section{Wybrane zagadnienia nowych regulacji dotyczących wydobywania węglowodorów}

Ze względu na obszerność zagadnienia, omówione zostaną wybrane zmiany w ustawie - Prawo geologiczne i górnicze ${ }^{11}$ oraz w innych aktach prawnych związanych z ochroną środowiska. Przedmiotem analizy jest jedynie projekt nowelizacji przepisów związanych z wydobywaniem węglowodorów, choć jego znaczenie oraz obszerna materia przemawiają za wskazaniem kilku wartych uwagi kwestii. Projekt został przedstawiony do konsultacji społecznych oraz uzgodnień międzyresortowych w dniu 15 lutego 2013 r. W ich wyniku wpłynęło około stu pism z uwagami dotyczącymi projektów ustaw. Oprócz obaw natury ekonomicznej (rentowność przedsięwzięć), krytyce poddano konkretne przepisy, między innymi sens istnienia Narodowego Operatora Kopalin Energetycznych (posiadającego udziały w każdej koncesji) oraz wiele przepisów związanych z ochroną środowiska.

Opisany wcześniej proces szczelinowania hydraulicznego wymaga dużych zasobów wodnych. Jako potencjalne źródła zaopatrzenia, oprócz wód powierzchniowych, wymieniane są m.in. solanki płytszych formacji, wody poprodukcyjne oraz oczyszczony płyn zwrotny. Wspomniane wcześniej w opisie procesu szczelinowania związki chemiczne są już kwestią bardziej kontrowersyjną. Wynoszą one $0,5 \%$ (niekiedy do 2\%) płynu szczelinującego i zgodnie z prawem ich skład miał stanowić tajemnicę przedsiębiorstwa. W projekcie zmiany ustawy - Prawo geologiczne i górnicze do art. 108 dotyczącego treści planu ruchu zakładu górniczego zaproponowano jednak dodanie ust. 11b. Informacja zawarta w planie ruchu zakładu górniczego z ust. 9a (czyli w planie ruchu zakładu górniczego dla wykonywania robót geologicznych związanych z rozpoznawaniem złóż) oraz planie ruchu zakładu górniczego związanym z wydobywaniem węglowodorów ze złóż, dotycząca składu płynu szczelinującego, ${ }^{12}$ nie stanowiłaby tajemnicy przedsiębiorcy $\mathrm{w}$ rozumieniu art. 5 ustawy o dostępie do informacji publicznej. ${ }^{13}$ Propozycję zmiany należy ocenić pozytywnie z punktu widzenia prawa do informacji o środowisku. W odniesieniu do związków chemicznych wykorzystywanych jako składnik płynu szczelinującego za-

11 Ustawa z dnia 4 lutego 1994 r. - Prawo geologiczne i górnicze (Dz.U. 1994 Nr 27, poz. 96 z późn. zm.).

12 Projekt ustawy o zmianie ustawy - Prawo geologiczne i górnicze, http://legislacja.rcl.gov.pl/dokument/135357 (dostęp: 10.06.2013 r.).

13 Ustawa z dnia 6 września 2001 r. o dostępie do informacji publicznej (Dz.U. z 2001 r. Nr 112, poz. 1198 ze zm.). 
stosowanie mają regulacje ustawy o substancjach chemicznych i ich mieszaninach ${ }^{14}$ oraz rozporządzenie $\mathrm{REACH} .^{15}$

Kolejna zmiana dotyczy ustawy z dnia 3 października 2008 r. o udostępnianiu informacji o środowisku i jego ochronie, udziale społeczeństwa w ochronie środowiska oraz o ocenach oddziaływania na środowisko. ${ }^{16}$ Proponowane brzmienie art. 44 ust. 1: „1. Organizacje ekologiczne, które powołując się na swoje cele statutowe, zgłoszą chęć uczestniczenia w określonym postępowaniu wymagającym udziału społeczeństwa, uczestniczą w nim na prawach strony, jeżeli prowadzą działalność statutową w zakresie ochrony środowiska lub ochrony przyrody, przez minimum 12 miesięcy przed dniem wszczęcia tego postępowania. Przepisu art. $31 \S 4$ Kodeksu postępowania administracyjnego nie stosuje się." Cytowany wymóg prowadzenia działalności statutowej w zakresie ochrony środowiska lub ochrony przyrody przez co najmniej rok przed dniem wszczęcia postępowania ma na celu ,zwiększenie pewności postępowań administracyjnych". Proponowana zmiana art. 44 została negatywnie zaopiniowana przez organizacje społeczne ${ }^{17}$ jako ograniczająca prawa części społeczności lokalnych do uczestnictwa w postępowaniu. Wątpliwości wzbudziła także niejasność przepisu i to, że będzie odnosił się nie tylko do postępowań związanych z węglowodorami, ale do wszystkich postępowań w sprawie oceny oddziaływania na środowisko.

Inną proponowaną zmianą wyżej wymienionej ustawy był brak wymogu uzyskania decyzji o środowiskowych uwarunkowaniach w przypadku zmiany:

- głębokości robót geologicznych związanych z rozpoznawaniem złóż kopalin, wykonywanych metodą otworów wiertniczych;

- koncesji lub decyzji, polegającej na zmianie terminu rozpoczęcia działalności lub ograniczeniu prowadzenia działalności objętej koncesją lub decyzją, o ile mieści się ono w zakresie objętym decyzją o środowiskowych uwarunkowaniach;

- zakresu i harmonogramu prac i robót geologicznych nie stanowiących przedsięwzięcia mogącego znacząco oddziaływać na środowisko lub przedsięwzięcia mogącego potencjalnie znacząco oddziaływać na środowisko;

- przy jednokrotnym wydłużeniu terminu obowiązywania koncesji na rozpoznawanie złóż węglowodorów i wydobywanie węglowodorów ze złóż do dwóch lat bez rozszerzenia zakresu koncesji;

14 Ustawa z dnia 25 lutego 2011 r. o substancjach chemicznych i ich mieszaninach (Dz.U. $2011 \mathrm{Nr} 63$, poz. 322).

15 Rozporządzenie (WE) NR 1907/2006 Parlamentu Europejskiego i Rady z dnia 18 grudnia 2006 r. w sprawie rejestracji, oceny, udzielania zezwoleń i stosowanych ograniczeń w zakresie chemikaliów (REACH) i utworzenia Europejskiej Agencji Chemikaliów, zmieniające dyrektywę 1999/45/WE oraz uchylające rozporządzenie Rady (EWG) nr 793/93 i rozporządzenie Komisji (WE) nr 1488/94, jak również dyrektywę Rady 76/769/EWG i dyrektywy Komisji 91/155/EWG, 93/67/EWG, 93/105/WE i 2000/21/WE (Dz.U.UE L 136/3 z 29.05.2007 r.).

16 Ustawy z dnia 3 października 2008 r. o udostępnianiu informacji o środowisku i jego ochronie, udziale społeczeństwa w ochronie środowiska oraz o ocenach oddziaływania na środowisko (Dz.U. Nr 199, poz. 1227, z późn zm.)

17 Wnioski i opinie Konferencji Klimatycznej będącej porozumieniem 23 organizacji pozarządowych, http://legislacja.rcl.gov.pl/dokument/153988, (dostęp: 04.06.2013 r.). 
- terminu rozpoczęcia prac i robót geologicznych;

- zapisu dotyczącego przekazywania próbek i danych geologicznych;

- przy zmniejszeniu granic obszaru i terenu górniczego. ${ }^{18}$

Jak zauważono w opinii o zgodności projektu z prawem Unii Europejskiej, ${ }^{19}$ cytowana propozycja wydawała się niezgodna z przepisami dyrektywy Parlamentu Europejskiego i Rady w sprawie oceny skutków wywieranych przez niektóre przedsięwzięcia publiczne i prywatne na środowisko. ${ }^{20}$

Osobną kwestią wymagającą oceny była próba zmian kompetencji organów ochrony środowiska. W pierwszym projekcie zadania z zakresu nadzoru geologicznego miały być realizowane przez Głównego Inspektora Ochrony Środowiska i Nadzoru Geologicznego i wojewódzkie inspektoraty ochrony środowiska i nadzoru geologicznego. Oznaczało to znaczne poszerzenie kompetencji GIOŚ i według Ministerstwa Środowiska znaczące wzmocnienie funkcji kontrolnych. Wątpliwości, czy tak diametralna zmiana w systemie organizacji ochrony środowiska byłaby zasadna, czy też stanowiłaby rozwiązanie iluzoryczne i niepotrzebnie, rozstrzygnięte zostały w nowej wersji projektu z dnia 13 czerwca 2013 r., który uwzględnił uwagi podmiotów społecznych. ${ }^{21}$

\section{Podsumowanie}

Analizując wszystkie czynniki można stwierdzić, że niemożliwe wydaje się, aby proces wydobywania węglowodorów nie miał negatywnego wpływu na środowisko. Kwestią zasadniczą jest jedynie ocena, jak duża może to być szkodliwość. Kluczowym zadaniem jest więc zintensyfikowanie działań mających na celu minimalizację szczególnie ujemnego wpływu na poszczególne elementy przyrodnicze poprzez kompleksową ocenę ryzyka środowiskowego. Podyktowane realizacją z góry powziętych założeń (,,zapewnienie Państwu odpowiedniego udziału w zyskach związanych z eksploatacją surowców naturalnych należących do Państwa", koncepcja Funduszu Pokoleń) i przyspieszone prace nad ustawą nie sprzyjają opracowaniu niezawodnych i przemyślanych przepisów zgodnych z zasadą zrównoważonego roz-

18 Założenia do projektu ustawy o zmianie ustawy - Prawo geologiczne i górnicze, http://legislacja.rcl.gov.pl/dokument/135357 (dostęp: 05.06.2013 r.).

19 http://legislacja.rcl.gov.pl/dokument/153877 (dostęp: 02.06 .2013 r.).

20 Dyrektywa Parlamentu Europejskiego i Rady Nr 2011/92/UE z dnia 13 grudnia 2011 r. w sprawie oceny skutków wywieranych przez niektóre przedsięwzięcia publiczne i prywatne na środowisko (Dz.U.UE.L.2012.26.1). 21 „Podnoszono również argumenty w sprawie domniemanego wzrostu biurokracji poprzez tworzenie nowych urzęwersji projektu zrezygnowano z tworzenia odrębnego urzędu, natomiast przekazano dodatkowe zadania Ministrowi Środowiska, co pociaga za sobą konieczność wzmocnienia kadrowego i finansowego urzędu obsługującego Ministra Środowiska". Ocena Skutków Regulacji projektu ustawy o zmianie ustawy - Prawo geologiczne i górnicze oraz niektórych innych ustaw, http://legislacja.rcl.gov.pl/dokument/161439 (dostęp: 13.06 .2013 r.), s. 26. 
Przegląd wybranych propozycji zmian legislacyjnych w przepisach dotyczących...

woju. W swoim pierwotnym kształcie, przed skierowaniem na konsultacje oraz do uzgodnień międzyresortowych, proponowane zmiany pozostawały w konflikcie z przepisami unijnymi, a zmiana niektórych przepisów miała znaczący wpływ nie tylko na procesy związane $\mathrm{z}$ poszukiwaniem, rozpoznawaniem i wydobywaniem gazu łupkowego, ale także na inne przedsięwzięcia środowiskowe.

Ochrona interesów przyszłych pokoleń nie powinna sprowadzać się wyłącznie do potencjalnych korzyści płynących z wydobywania gazu łupkowego, takich jak zwiększenie bezpieczeństwa energetycznego, nowe miejsca pracy w sektorze energetycznym oraz poprawa sytuacji ekonomicznej. Niezbędne są gwarancje, że dla przyszłych pokoleń nie nastąpi trwałe, nieodwracalne pogorszenie się stanu środowiska. Nawet pobieżna analiza projektowanej regulacji (a także jego nowej wersji) daje podstawy do stwierdzenia, że takie gwarancje nie zostały jeszcze w pełni udzielone.

\section{BIBLIOGRAFIA}

Ciechanowicz-McLean J., Prawnośrodowiskowe uwarunkowania wydobywania gazu łupkowego w Polsce, [w:] T. Bąkowski, K. Żukowski (red.), Gdańskie Studia Prawnicze - Studia prawnoadministracyjne. Księga Jubileuszowa profesora Eugeniusza Bojanowskiego, Tom XVIII, Gdańsk 2012.

Haładyj, A., Środowisko - pojęcie, [w:] M. Domagała, A. Haładyj, S. Wrzosek (red.), Encyklopedia Prawa Administracyjnego, Warszawa 2010.

Jabłoński, M., Zasada zrównoważonego rozwoju jako administracyjnoprawny aspekt działania administracji publicznej w Polsce, [w:] M. Rudnicki, M. Jabłoński, K. Sobieraj (red.), Nowoczesna administracja publiczna. Zadania i działalność - uwarunkowania prawne, Lublin 2013.

Macuda, J., Środowiskowe aspekty produkcji gazu ziemnego z niekonwencjonalnych złóż, „Przegląd Geologiczny" 2010, vol. 58, nr 3. 


\section{AN OVERVIEW OF SELECTED PROPOSED LEGISLATIVE CHANGES IN RULES FOR SHALE GAS EXPLORATION}

Regulations developed for the exploration and production of natural gas from unconventional gas fields should be based on the principle of sustainable development and environmental protection. There are concerns that some provisions of the new law do not provide required levels of protection to elements of the environment. The legislator should endeavour to ensure that the law is wholly fit for purpose and especially so considering that hydraulic fracturing constitutes a potential danger to the environment. The principle of sustainable development is an important consideration in the pursuit of energy security and the related development of mineral resources.

Keywords: shale gas, sustainable development, environmental law 